\title{
Application of the Huff Model of Shopping Probability in the Selected Stores in Prešov (Prešov, the Slovak Republic)
}

\author{
Jana MitríkováA*, Anna ŠenkováA, Sandra AntolikováA \\ Received: March 25, 2015 | Revised: June 15, 2015 | Accepted: September 1, 2015
}

\begin{abstract}
The main objective of this article is the calculation of the Huff Model and the comparison of obtained data with the questionnaire survey results. Afterwards, we will try to assess the validity of this theoretical model of shopping probability for practical use as well as its overall objectivity.

Calculation of the Huff Model of Probability will be calculated for nine large-scale retail stores in fifteen local regions within the area of the third largest town in the Slovak Republic - Prešov. These results will be compared to results of the questionnaire research which was conducted during the period of November 2013 until March 2014 on a sample of 1,096 respondents. The questionnaire was addressing customers' preference for various large-scale stores as well as their place of residence. Based on the calculation results and the results obtained from the questionnaire survey, cartographic outputs were created, pointing out overall consistency as well as differences in the already mentioned results.
\end{abstract}

Key words: retail store, Prešov, gravity models, Huff Model, large - scale retail stores

\section{Introduction}

Over the last twenty five years, Slovak retail market has undergone major changes. Transition from the central retail directive management to market economy has been in the context of socio-political changes after 1989, making this transition a complex transformation process (Mitríková, 2205, 2008, 2010a, 2010b; Szcyrba, 2005a; Trembošová, 2012). This process was influenced by small and large-scale privatization and atomization of the retail network, characterized by the emergence of a large number of individual sale units without any vertical or horizontal cooperation (Trembošová, Dubcová, 2013). In the next stage, the stage of concentration and internationalization, foreign retail stores entered the Slovak retail market, creating a highly competitive environment. These multinational companies in a relatively short period of time made their projects, the construction of large stores (discount stores, supermarkets, hypermarkets, shopping centers, etc.) which fundamentally changed the functional and spatial model of the city (Matlovič, et al., 2001; Szczyrba 2005a; Križan, 2009; Trembošová 2010, 2012; Kunc, 2013; Trembošová, Dubcová, 2013). Large retail units were placed closer to major transport routes, often called "greenfield", causing a change in the traditional shopping behavior of consumers (in terms of weekend shopping, shopping for pleasure, destination change and so on (Mitríková, 2008; Križan 2009; Spilková, 2011; Spilková, 2012; Trembošová, 2012; Kunc, et al., 2013; Civáň, et al., 2014).

According to Križan and Lauko (2014), a suitable research tool for retail chains can be considered modelling, expressing the relationships of store localization to different variables. The literature dedicated to the retail sector differentiates several model types; from the simplest gravity model to challeng-

\footnotetext{
A Faculty of Management, University of Prešov, Konštantínova ul. 16, 08001 Prešov, Slovak Republic; jana.mitrikova@unipo.sk, anna.senkova@unipo.sk, sandra.antolikova@unipo.sk

Corresponding author: Jana Mitríková, e-mail: jana.mitrikova@unipo.sk
} 
ing multivariable models (see Szczyrba, 2005, 2006; Trembošová, 2008, 2010; Križan, Tolmáči, 2012; Linhart, Križan, 2014; Kunc, et al. 2013 and others). Models which are being applied in the retail geography are based on the concept of human aggregate gravity, developed by Reilly (1931), Huff $(1963,1964)$ and other authors. Application of the Huff model for Slovak retail stores has already been discussed by Mitríková, Varga (2007, 2008) in Košice and Trembošová (2008) in Nitra. In this article, the application of Huff model will be examined in relation to selected large-scale retail outlets in Prešov, and the results will be compared to the results of the questionnaire survey.

\section{Methods and data}

Gravity models are the most commonly used types of spatial models. They are based on the analogy with the Newton's law of gravity (Szczyrba, 2006; Kunc, et al. 2013). At first, gravity models were used only for the demographic research. From the 1930s, their use has been extended even to define the areas of commercial service centers (Szczyrba, 2006). The gravity model, functioning as an interactional model, is geographically considered to be a traditional tool for the quantitative analysis of spatial interaction (Mitríková, 2008). The most famous gravity model is the Reilly's law of retail gravitation (Reilly, 1929, 1931) which reflects the fact, that two major centers share the allocated demand of the place lying between them, in proportion to the population of both sites and inversely to the distance of both locations to an intermediate point. However, this model can distort the reality, as it regards the sphere of centers' influence as closed and mutually exclusive. On the other side, studies have proved the existence of a transitional area, in which residents commute due to shopping to two or more centers. This model does not take into consideration other aspects that affect the distribution of residents' money spending, such as transportation links, population density, income as well as social differentiation of consumers. Thus, there are certain limitations in relation to this model. In urban areas, there are more shopping possibilities, thus increasing the choice. Due to these facts, the traditional form of the two-site interaction model was adjusted by Huff (Huff, 1962, 1963, 1964). Therefore, this model was used in the paper to calculate the theoretical probability of customers' shopping in all large-scale retail stores in Prešov.

The Huff Probability Model takes into account the size of retail, which is measured by its area as well as availability. This model defines the proportion of customer shopping journeys from certain places into all shopping centers of the studied area. This proportion can be understood as the probability, that a store will be selected as a target by consumers of a certain location. The Huff Probability Model is widely used in practice, and it has been the most frequently used model since the mid-7os of the 2oth century. Huff (1964) states the justification of this model as follows:

As the result of a trading area which incorporates various survey techniques, a number of important empirical regularities have been shown to exist:

1. The proportion of consumers patronizing a given shopping area varies with distance from the shopping area.

2. The proportion of consumers patronizing various shopping areas varies with the breadth and depth of merchandise offered by each shopping area.

3. The distances that consumers travel to various shopping areas vary depending on different types of product purchases.

4. The „pull“of any given shopping area is influenced by the proximity of competing shopping areas.

Even though it is a model with a wide range of applications, the problem is still the complementation of each trait. Its mathematical expression is as follows:

$$
P_{i j}=\frac{\frac{S_{j}}{T_{i j}{ }^{a}}}{\sum_{j=1}^{n} \frac{S_{j}}{T_{i j}{ }^{a}}}
$$

$P_{i j}$ - probability of a consumer at a given point of origin $\mathbf{i}$ traveling to a particular shopping centre $\mathbf{j}$;

$S_{j}$ - size of a shopping center $\mathbf{j}$ (measured in terms of square meters of the shopping area);

$T_{i j}$ - travel time or distance involved in getting from a consumer's travel base $\mathbf{i}$ to a given shopping centre $\mathbf{j}$;

$n$ - number of all possible shopping places in the area $a$ - parameter expresses the customer's willingness to overcome a certain distance

Prešov, which is the subject of this research, lies in the central part of Eastern Slovakia, on the eastern edge of Šariš highlands and on the northern edge of the Košice basin. An absolute current position is given the coordinates: $49^{\circ}$ n. w. $w$ and $21^{\circ} 15^{\prime}$ e. w. 1 . The altitude of the historical center is about 255 meters above the sea level, at the confluence of rivers, with the altitude of 233 meters above the sea level. Prešov is by the population considered to be the third largest city in Slovakia (following Bratislava and Košice) and on 31 of December 2014, there were 87,586 inhabitants (eGovernment town Prešov, 2015). Prešov serves as an important transportation hub. That situation arises directly from its history, when it was one of the important nodes on the traditional cross- 
ing of roads. The town has a west-eastern road moving towards Czech Republic - Žilina - Prešov - Vyšné German - Ukraine and north-southern road towards the Republic of Poland - Vyšný Komárnik - Svidnik Prešov - Kosice - Milhost' - Hungary. The strategic position is also in rail services within the north-southern rail corridor, connecting the Republic of Poland and Hungary (Matlovič, 1998; Hochmuth, et al., 1994).

The area of Prešov was in this research divided into 15 local regions (Matlovič, 1998) (Figure 1), which were developed on the basis of observational unit analysis of the socio-demographic structure of Prešov by Matlovič (1998), with the localization of 9 large - scale retail stores. Some of these local regions are identical with the observational units (these are: Historical center, Mlynský náhon, Prešov- South, Calvary, Šalgovík and Šváby). Other local regions were created by merging several observational units into one local region, for example the local region Sekčov was creat- ed by combining observational units Sekčov I, Sekčov II., Sekčov III., and Sekčov IV, or in other words Sídlisko III which includes observational units Rúrky, Družba, Pod Bikošom and Mladost'. The unification of several observational units into one local region was based on spatial and morphological proximity of spatial units, but mainly on the similarity of parameter values required for calculations. The researched territory comprises 15 local regions, each of which includes the parameter "i" as a site where the calculation of availability was measured, in this case, the distance to selected shops “ $j$ ”. To find the information on the distance, we measured the shortest distance that can be reached by using a road network from the city center " $j$ " to the geometrical center of gravity of each local region " $i$ ". These data were found using the tool to view the shortest path between two given points in the Google Maps website. Data obtained represent the value of "Tij" - the distance.

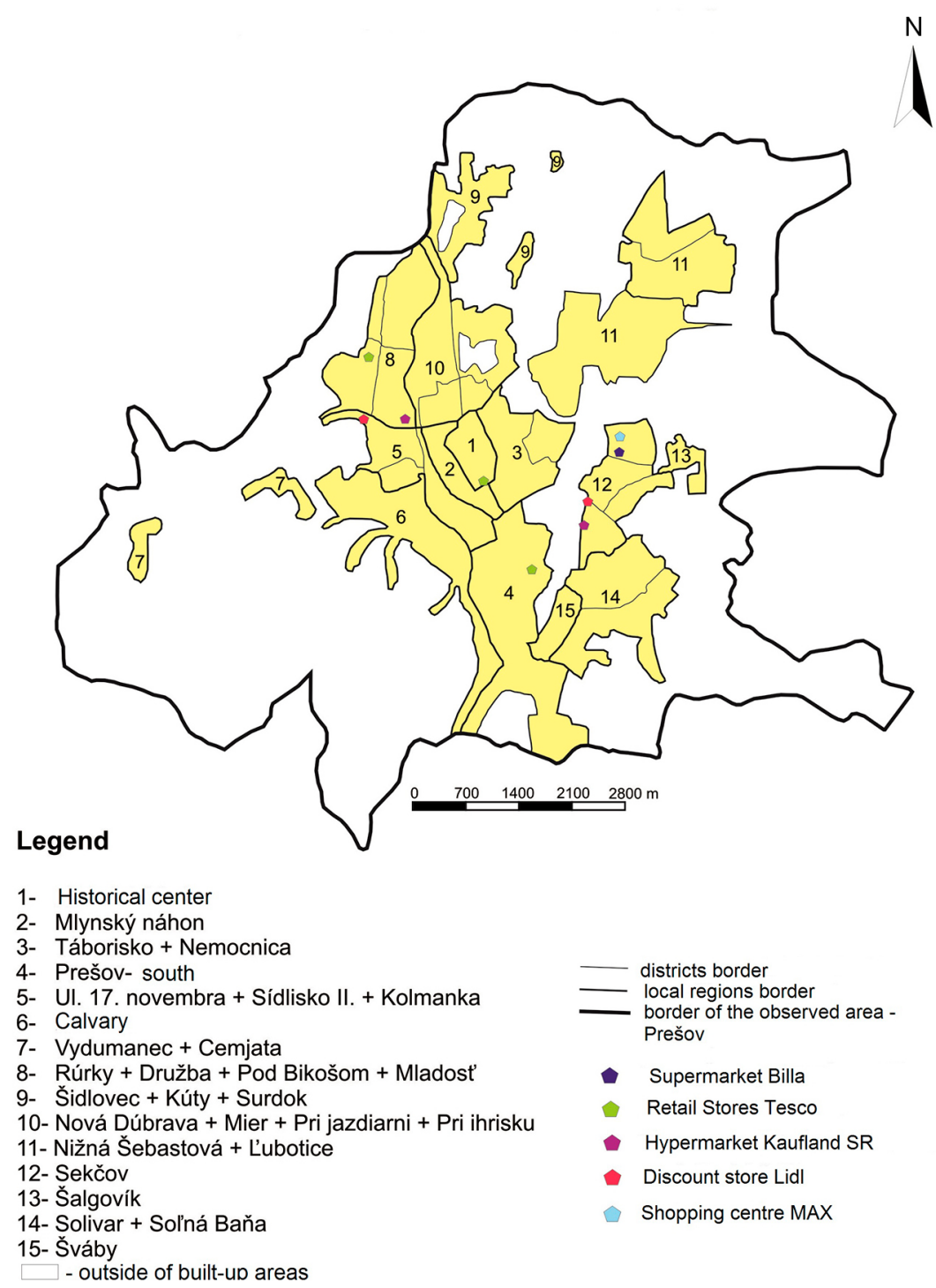

Figure 1. Localization of large-scale retail stores within the area of Prešov Source: Authors research 
Table 1. The distance of local regions I from the selected large - scale stores $\mathrm{j}(\mathrm{km})$

\begin{tabular}{|c|c|c|c|c|c|c|c|c|c|c|}
\hline \multirow{2}{*}{\multicolumn{2}{|c|}{ Local region- $\mathrm{i}$}} & \multicolumn{3}{|c|}{ Tesco } & \multicolumn{2}{|c|}{ Lidl } & \multicolumn{2}{|c|}{ Kaufland } & \multirow{3}{*}{$\begin{array}{c}\text { Billa } \\
3.6\end{array}$} & \multirow{3}{*}{$\begin{array}{c}\text { ZOC } \\
\text { MAX } \\
4.1\end{array}$} \\
\hline & & \multirow{2}{*}{$\frac{\text { Nám. legionár. }}{0.55}$} & \multirow{2}{*}{$\begin{array}{c}\text { Košická } \\
2.5\end{array}$} & \multirow{2}{*}{$\frac{\text { Vukov }}{2.8}$} & \multirow{2}{*}{$\frac{\text { Rusínska }}{2.9}$} & \multirow{2}{*}{$\frac{\text { Levočská }}{2.2}$} & \multirow{2}{*}{$\begin{array}{c}\text { Sekčov } \\
3.3\end{array}$} & \multirow{2}{*}{$\begin{array}{c}\text { Levočská } \\
1.4\end{array}$} & & \\
\hline 1 & Historical centre & & & & & & & & & \\
\hline 2 & Mlynský náhon & 0.55 & 1.9 & 2.7 & 2.3 & 2.1 & 2.8 & 1.3 & 3.1 & 3.6 \\
\hline 3 & Táborisko, Nemocnica & 1.0 & 2.2 & 4.1 & 2.0 & 3.5 & 2.5 & 2.7 & 2.7 & 3.3 \\
\hline 4 & Prešov- South & 2.5 & 1.4 & 4.9 & 2.9 & 4.2 & 3.2 & 3.4 & 3.8 & 4.3 \\
\hline 5 & $\begin{array}{l}\text { St. 17. Novembra } \\
\text { Sídlisko II. Kolmanka }\end{array}$ & 1.5 & 3.0 & 2.1 & 3.3 & 1.4 & 3.8 & 1.1 & 4.1 & 4.6 \\
\hline 6 & Kalvária & 2.5 & 2.9 & 3.0 & 3.8 & 2.3 & 4.3 & 2.1 & 4.5 & 5.1 \\
\hline 7 & Vydumanec Cemjata & 5.0 & 6.6 & 3.3 & 6.8 & 2.6 & 7.3 & 3.5 & 7.6 & 8.1 \\
\hline 8 & Sídlisko III. & 3.7 & 5.1 & 0.45 & 5.4 & 1.3 & 5.9 & 2.1 & 6.2 & 6.7 \\
\hline 9 & Šidlovec, Kúty, Surdok & 5.4 & 6.6 & 3.9 & 6.4 & 5.1 & 6.9 & 4.3 & 7.2 & 7.7 \\
\hline 10 & $\begin{array}{l}\text { Nová Dúbrava, Mier, } \\
\text { Pri jazdiarni, Pri ihrisku }\end{array}$ & 2.6 & 3.8 & 1.7 & 3.6 & 2.4 & 4.1 & 1.9 & 4.4 & 4.9 \\
\hline 11 & $\begin{array}{l}\text { Nižná Šebastová } \\
\text { L'ubotice }\end{array}$ & 5.3 & 6.5 & 6.1 & 4.4 & 5.4 & 4.5 & 5.2 & 3.6 & 3.3 \\
\hline 12 & Sekčov & 2.5 & 2.8 & 5.6 & 0.75 & 4.9 & 0.85 & 4.2 & 1.4 & 1.9 \\
\hline 13 & Šalgovík & 4.0 & 4.1 & 6.9 & 2 & 6.3 & 2.1 & 5.5 & 2.7 & 3.2 \\
\hline 14 & Solivar, Sol'ná Baňa & 3.5 & 2.1 & 6.5 & 2 & 5.8 & 1.9 & 5.1 & 2.5 & 3.0 \\
\hline 15 & Šváby & 3.5 & 2.7 & 6.6 & 3 & 5.9 & 2.5 & 5.1 & 3.7 & 4.2 \\
\hline
\end{tabular}

Source: http://maps.google.com/

Explanation: 8.1 - the longest distance in kilometers from the store to the geometric centre of the local region (this information is given for each large-scale store); 0.55 - the shortest distance in kilometers from the store to the geometric center of the local region (this information is given for each large-scale store) between the local region "i" and the store "j" (see Table 1).

Other data that were necessary for the calculation of probability include the attractiveness of individual stores - which is determined by their retail space. Parameter "a" represents customers' willingness to overcome a certain distance. It is empirically determined and varies with the hierarchical level of the centre. Given the similarity of stores with a comparable supply of goods and supposedly similar attraction of stores for the customer, each store was assigned the parameter 1 . In the calculations, the denominator was the sum of the retail space size and the distance to local regions, regarding all shopping place options within the area of Prešov (two discount stores Lidl SR, supermarket Billa, the department store and two hypermarkets Tesco Stores SR, two hypermarkets Kaufland SR and a shopping centre MAX). Substituting the obtained results into the formula, we achieved the choice probability for every target retail store in relation to the population of each of the fifteen local regions in Prešov. The results of calculations are shown in the Table 2. From the results of the Huff model application, we created the maps of the choice probability, made by motorized store customers, using the single legend for all of them due to their relative comparability as well as comparability of maps which were based on the results of the questionnaire research (conduct- ed on a sample of 1,096 respondents from November 2013 to March 2014). It is a questionnaire survey by Kunc et al. (2013), the most common way of getting data in shopping surveys within the selected large-scale retail units, namely the method to query respondents directly in hypermarkets and shopping malls, or in close proximity (parking), where they are asked questions designed to determine the shopping frequency, shopping site preferences and others. (such research was carried by Mary 1983 Szczyrba, 2005a, 2005b; Mitríková 2008; Mitríková, Menyhértová 2008; Trembošová, 2012; Mitríková, Tomčíková, Lukáčová, 2012; Kunc et al., 2012a, 1012b, 2013; Trembošová, Dubcová , 2013; Civáň et al., 2014; Maryáš et al., 2014 and others).

\section{Results}

Detailed results of calculations in comparison with the results of the questionnaire survey in tables and maps were analyzed for those large-scale retail stores whose results were the most interesting or unexpected. We have chosen the store with the largest floor space - MAX shopping centre, a supermarket Billa, located in close proximity to the MAX, as the smallest retail store and a Tesco department store with a unique location in the historical centre. 


\section{Shopping centre MAX}

On the outskirts of the housing estate Sekčov (with the population of about 27,000 , it is the largest housing estate in Prešov) with the shopping area of 19,950 $\mathrm{m}^{2}$, we can find the shopping centre MAX. The shopping mall is connected to the hypermarket Hypernova, with five cinema halls for 860 spectators, dining area and 115 retail stores.

According to the calculations of the Huff model, Max has the highest probability from all large-scale retail stores, within the area of eleven from fifteen local regions, to be chosen by customers (Table 2). Looking at the practical results of this probability model for the shopping centre MAX (Table 2 and Figure 2), it can be found that the studied area of the town Prešov has most likely routes for customers leading to the shopping centre MAX from the local regions lying in the nearest centre. On the other hand, the smallest shopping possibility at this resort was found in local regions that are further away from the centre. However, it is interesting to point out that the largest probable shopping share is not achieved by the local region Sekčov (0.466, which is almost $47 \%$ ), including the shopping centre MAX, but local regions Nižná Šebastová and Lubotice (0.575, which is $57.5 \%)$. This fact points out that the availability of a good shopping centre is not the only parameter in the calculation of the store shopping probability, but the choice is also affected by the localization of other stores in Prešov, their proximity to the local region Sekčov and their attractiveness via the area size.

This fact proves that there are also other shops in the local region Sekčov (supermarket Billa, Kaufland hypermarkets and discount stores Lidl which make the shopping center MAX less).

The lowest value of share purchases in the shopping centre MAX achieves the local region Sídlisko III (o.191, less than one-fifth share of the local region), which is not only one of the outermost shopping centers MAX, but in that local region or in the close proximity, there are located hypermarkets Tesco and Kaufland and Lidl discount stores. Real preferences for shopping and visiting the shopping centre MAX (Vihorlatská street. - the local region Sekčov), were found by the questionnaire survey among 1,096 inhabitants of Prešov (residing in different local regions). The results of this large-scale retail store preferences are stated in the Table 3 and the Figure 3. In comparison with the theoretical model (Table 2), the values of the shopping centre MAX (Table 3 ) do not

Table 2. Choice probability of the retail store $\mathrm{j}$ by motorized customers in the area $\mathrm{i}$

\begin{tabular}{|c|c|c|c|c|c|c|c|c|c|c|}
\hline \multirow{2}{*}{\multicolumn{2}{|c|}{ local region- $\mathrm{i}$}} & \multicolumn{3}{|c|}{ Tesco } & \multicolumn{2}{|c|}{ Lidl } & \multicolumn{2}{|c|}{ Kaufland } & \multirow{2}{*}{ Billa } & \multirow{2}{*}{$\begin{array}{l}\text { ZOC } \\
\text { MAX }\end{array}$} \\
\hline & & Nám. legionár. & Vukov & Košická & Rusínska & Levočská & Sekčov & Levočská & & \\
\hline 1 & Historical centreo & 0.314 & 0.143 & 0.055 & 0.021 & 0.028 & 0.054 & 0.125 & 0.012 & 0.248 \\
\hline 2 & Mlynský náhon & 0.318 & 0.161 & 0.048 & 0.023 & 0.025 & 0.055 & 0.115 & 0.012 & 0.243 \\
\hline 3 & Táborisko, Nemocnica & 0.224 & 0.178 & 0.041 & 0.034 & 0.019 & 0.078 & 0.071 & 0.017 & 0.338 \\
\hline 4 & Prešov- South & 0.108 & 0.336 & 0.041 & 0.028 & 0.019 & 0.073 & 0.068 & 0.015 & 0.312 \\
\hline 5 & $\begin{array}{l}\text { Ul. 17. novembra, } \\
\text { Sídlisko II., Kolmanka }\end{array}$ & 0.164 & 0.144 & 0.088 & 0.022 & 0.053 & 0.057 & 0.192 & 0.012 & 0.268 \\
\hline 6 & Kalvária & 0.129 & 0.194 & 0.081 & 0.026 & 0.042 & 0.065 & 0.132 & 0.015 & 0.316 \\
\hline 7 & Vydumanec, Cemjata & 0.107 & 0.142 & 0.122 & 0.024 & 0.062 & 0.065 & 0.132 & 0.015 & 0.331 \\
\hline 8 & Sídlisko III. & 0.069 & 0.088 & 0.428 & 0.014 & 0.059 & 0.038 & 0.104 & 0.009 & 0.191 \\
\hline 9 & Šidlovec, Kúty, Surdok & 0.105 & 0.151 & 0.110 & 0.027 & 0.034 & 0.073 & 0.114 & 0.017 & 0.369 \\
\hline 10 & $\begin{array}{l}\text { Nová Dúbrava, Mier, } \\
\text { Pri jazdiarni, Pri ihrisku }\end{array}$ & 0.120 & 0.143 & 0,137 & 0.026 & 0.038 & 0.066 & 0.139 & 0.015 & 0.316 \\
\hline 11 & $\begin{array}{l}\text { Nižná Šebastová, } \\
\text { L'ubotice }\end{array}$ & 0.071 & 0.102 & 0.046 & 0.026 & 0.021 & 0.074 & 0.063 & 0.022 & 0.575 \\
\hline 12 & Sekčov & 0.071 & 0.111 & 0.024 & 0.071 & 0.011 & 0.183 & 0.036 & 0.027 & 0.466 \\
\hline 13 & Šalgovík & 0.078 & 0.134 & 0.034 & 0.047 & 0.015 & 0.131 & 0.049 & 0.024 & 0.488 \\
\hline 14 & Solivar, Sol'ná Baňa & 0.075 & 0.219 & 0.030 & 0.039 & 0.014 & 0.121 & 0.044 & 0.022 & 0.436 \\
\hline 15 & Šváby & 0.096 & 0.219 & 0.038 & 0.034 & 0.017 & 0.118 & 0.057 & 0.019 & 0.402 \\
\hline
\end{tabular}

Source: own calculations using the formula of the Huff Probability Model

Explanation: 0.575 - the highest probability value calculated for the local region; 0.011 - the lowest probability value calculated for the local region likely to be chosen than the local regions of Nižná Šebastová and L'ubotice, whose territory does not take pride in any largescale retail stores. Therefore, the shopping centre MAX is the closest and the most attractive large-scale store in this part of the town. On the other hand, for the same reason, the retail store Tesco makes the shopping shares of the local regions Historické jadro (0.248) and Mlynský náhon (0.243, which is almost a quarter of both local regions) lower than the local regions or surrounding districts. 


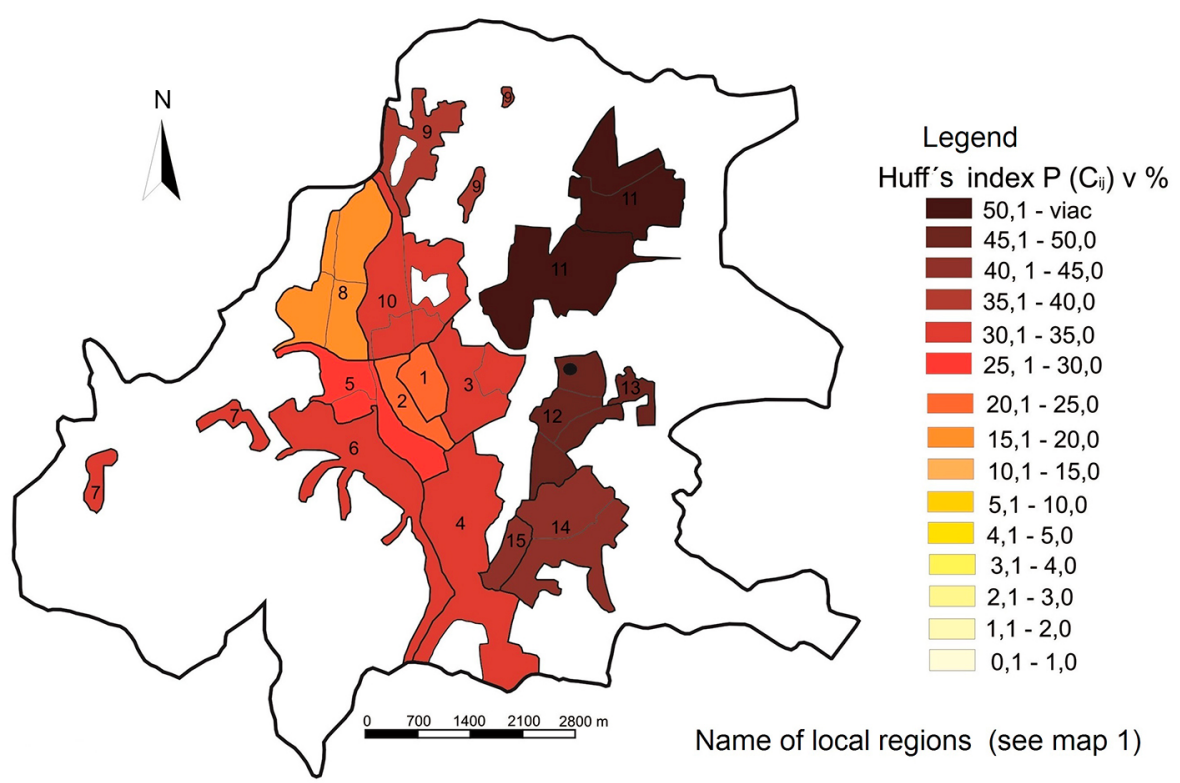

Figure 2. Selection probability of the shopping centre MAX by motorized customers Source: Authors research

reach such a significant proportion compared to other large-scale outlets.

The highest proportions of customers who prefer this shopping center to other outlets live in the local region Sekčov (18.8\% of the total number of inhabitants from this local region chose the shopping centre MAX), the housing estate Šváby (16.7\%) and the local region Kalvária (15.4\%). No respondents from the local

Table 3. Percentages of surveyed customers living in a certain local region preferring one large-scale retail store

\begin{tabular}{|c|c|c|c|c|c|c|c|c|c|c|}
\hline \multirow{2}{*}{\multicolumn{2}{|c|}{ local region- $\mathrm{i}$ retail store- $\mathrm{j}$}} & \multicolumn{3}{|c|}{ Tesco } & \multicolumn{2}{|c|}{ Lidl } & \multicolumn{2}{|c|}{ Kaufland } & \multirow{2}{*}{ Billa } & \multirow{2}{*}{$\begin{array}{l}\text { ZOC } \\
\text { MAX }\end{array}$} \\
\hline & & Nám. legionár. & Košická & Vukov & Rusínska & Levočská & Sekčov & Levočská & & \\
\hline 1 & Historical centre & 11.1 & 0.0 & 0.0 & 11.1 & 11.1 & 33.3 & 22.2 & 0.0 & 11.1 \\
\hline 2 & Mlynský náhon & 21.1 & 0.0 & 15.8 & 0 & 21.1 & 0 & 36.8 & 0.0 & 5.3 \\
\hline 3 & Táborisko, Nemocnica & 33.3 & 16.7 & 8.3 & 8.3 & 8.3 & 8.3 & 8.3 & 0.0 & 8.3 \\
\hline 4 & Prešov- South & 25.0 & 75.0 & 0.0 & 0.0 & 0.0 & 0.0 & 0.0 & 0.0 & 0.0 \\
\hline 5 & $\begin{array}{l}\text { Ul.17.novembra Sídlisko } \\
\text { II. Kolmanka }\end{array}$ & 9.9 & 8.6 & 7.4 & 3.7 & 30.9 & 2.5 & 28.4 & 3.7 & 4.9 \\
\hline 6 & Kalvária & 30.8 & 15.4 & 7.7 & 0.0 & 15.4 & 0.0 & 15.4 & 0.0 & 15.4 \\
\hline 7 & Vydumanec, Cemjata & 23.1 & 7.7 & 15.4 & 0.0 & 30.8 & 0.0 & 23.1 & 0.0 & 0.0 \\
\hline 8 & Sídlisko III. & 9.7 & 0.8 & 34.3 & 0.8 & 21.4 & 3.2 & 19.4 & 5.2 & 5.2 \\
\hline 9 & Šidlovec, Kúty, Surdok & 20.7 & 6.9 & 37.9 & 3.4 & 0.0 & 3.4 & 20.7 & 0.0 & 6.9 \\
\hline 10 & $\begin{array}{l}\text { Nová Dúbrava, Mier, } \\
\text { Pri jazdiarni, Pri ihrisku }\end{array}$ & 9.3 & 8.0 & 17.3 & 4.0 & 12.0 & 1.3 & 25.3 & 17.3 & 5.3 \\
\hline 11 & $\begin{array}{l}\text { Nižná Šebastová, } \\
\text { L'ubotice }\end{array}$ & 18.8 & 33.3 & 2.1 & 4.2 & 8.3 & 10.4 & 4.2 & 8.3 & 10.4 \\
\hline 12 & Sekčov & 7.3 & 8.3 & 2.3 & 14.3 & 1.0 & 21.6 & 1.5 & 24.9 & 18.8 \\
\hline 13 & Šalgovík & 5.7 & 20.0 & 5.7 & 22.9 & 0.0 & 25.7 & 2.9 & 8.6 & 8.6 \\
\hline 14 & Solivar, Sol'ná Baňa & 4.8 & 21.4 & 2.4 & 33.3 & 2.4 & 11.9 & 4.8 & 9.5 & 9.5 \\
\hline 15 & Šváby & 4.8 & 21.4 & 9.5 & 21.4 & 0.0 & 14.3 & 2.4 & 9.5 & 16.7 \\
\hline
\end{tabular}

Source: questionnaire survey conducted from November 2013 to March 2014 in the following areas of large stores: supermarket Tesco, hypermarket Tesco, Tesco Vukov, Lidl Levocska street, Lidl Rusínska street, ZOC MAX, Billa, Kaufland HM Levočska street. HM Kaufland on the street. Arm. gen. L. Svoboda in Prešov.

Explanation: $0.0 \%$ - the percentage of the total number of inhabitants in the particular local region preferring the given store as the destination of their regular purchases - the value for the local region is minimal; $75.0 \%$ - the percentage of the total number of inhabitants in the particular local region preferring the given store as the destination of their regular purchases - the value for the local region is maximal. 


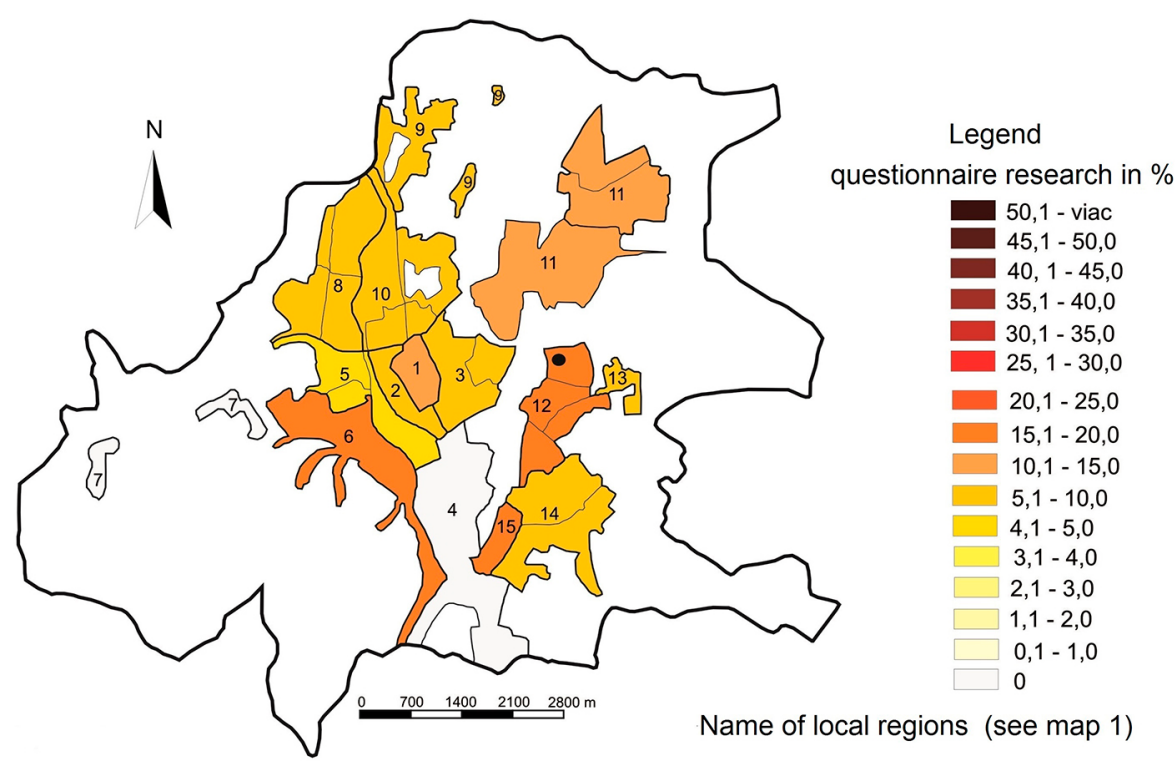

Figure 3. Frequency of visits of the shopping centre MAX (Vihorlatská street) in Prešov by the customers with the residence in Prešov Source: Authors questionnaire research

region Prešov - South and Vydumanec - Cemjata prefer their purchases to be done in the shopping centre MAX. The distance may be the limitation factor of this region, since it is $8.1 \mathrm{~km}$ from the shopping centre MAX (Table 1), which is the farthest large-scale retail store, from all nine researched. It is visible (Table 1) that the local region Vydumanec - Cemjata has the worst availability for most stores. The nearest shop is a discount store Lidl Levočska which is also preferred by the majority of the population (Table 3), although according to the theoretical Huff Model, potential customers should choose the shopping centre MAX (Table 2). This shows us that customers do not always prefer a large-scale retail store with a wide range of goods (MAX 7,00o m2 compared to Lidl 1,200 m2), but rather prefer the store with a good availability in relation to their residence (ZOC MAX $8.0 \mathrm{~km}$ compared to Lidl $2.6 \mathrm{~km}$ ).

\section{Billa supermarket}

Billa supermarket (with the area of $847 \mathrm{~m}^{2}$ ) is situated on the edge of the housing estate Sekčov, in the close proximity to the shopping centre MAX. The probability of the supermarket Billa selection (Čergovská street - local region Sekčov in Prešov) by the customers as the goal of their purchases, calculated by the Huff Model, achieved at this store lowest values (Table 2). These calculated values are very low and the differences between them are minimal, which is due to the fact that it is the smallest large-scale store in Prešov $\left(847 \mathrm{~m}^{2}\right)$ and there are also other large-scale stores in the surrounding area (ZOC MAX, Lidl and the hypermarket Kaufland, Figure 1) with more floor space, being reflected in the calculations and giving the supermarket Billa the smallest probability in case of the potential customer purchase selection. The largest value (even when compared to other local regions) is assigned to local regions in the immediate proximity (Table 2 and Figure 4), for example the local region Sekčov, on whose territory the store is located. Real preferences towards the Billa supermarket, found in the survey questionnaire (Table 3 and Figure 5), are compared to other stores very low (except for the local region Sekčov, which is significantly higher with a value of $24.9 \%$ and partially the local region Nová Dubrava, Mier, Pri jazdiarni and Pri ihrisko with 17.3\%). The respondents living in the local region Sekčov, the territory with the location of the Billa store, (which has been compared to other local regions much more, and almost a quarter of the total number of inhabitants live in this local region) who chose the supermarket Billa, the questionnaire indicated that the cause of Billa preference was the following: "we were in Max, so we went here as well" which means that the close proximity of two stores (about 10 meters) could actually affect the increase in the number of customers in the supermarket. The inhabitants of seven local regions do not make the shopping in Billa at all. Therefore, if we compare the results of the Huff Model calculations and the real results obtained by the questionnaire survey, it can be concluded that despite the low value of the theoretical model calculations, summarizing the real data (especially for the local regions, Sekčov, Nová Dúbrava, Mier, Pri jazdiarni and Pri ihrisku), there were very high values obtained, not being caused by the appeal of the supermarket Billa, but rather by the shopping centre MAX. This information was by the Huff Model considered to be rather negative, in connection with Billa preferences. 


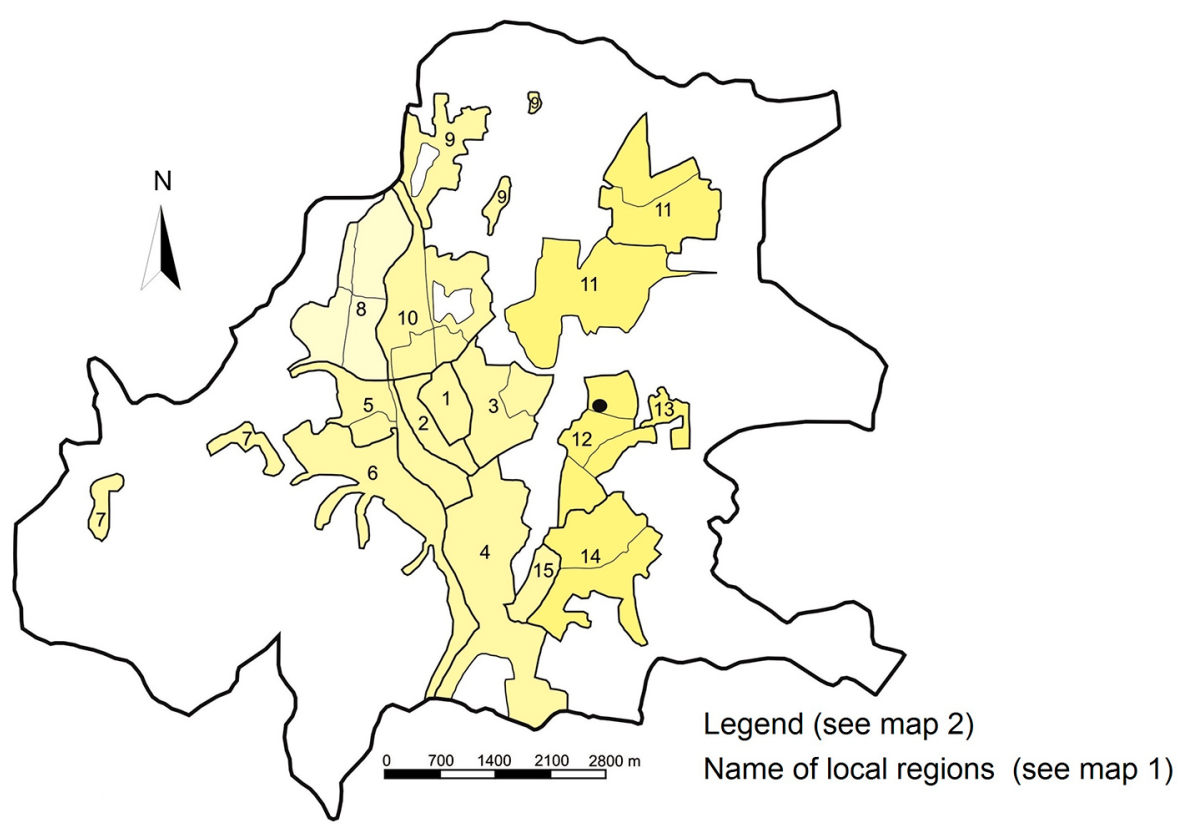

Figure 4. Selection probability of the retail store Billa (Čergovská street) in Prešov by motorized customers Source: Authors research

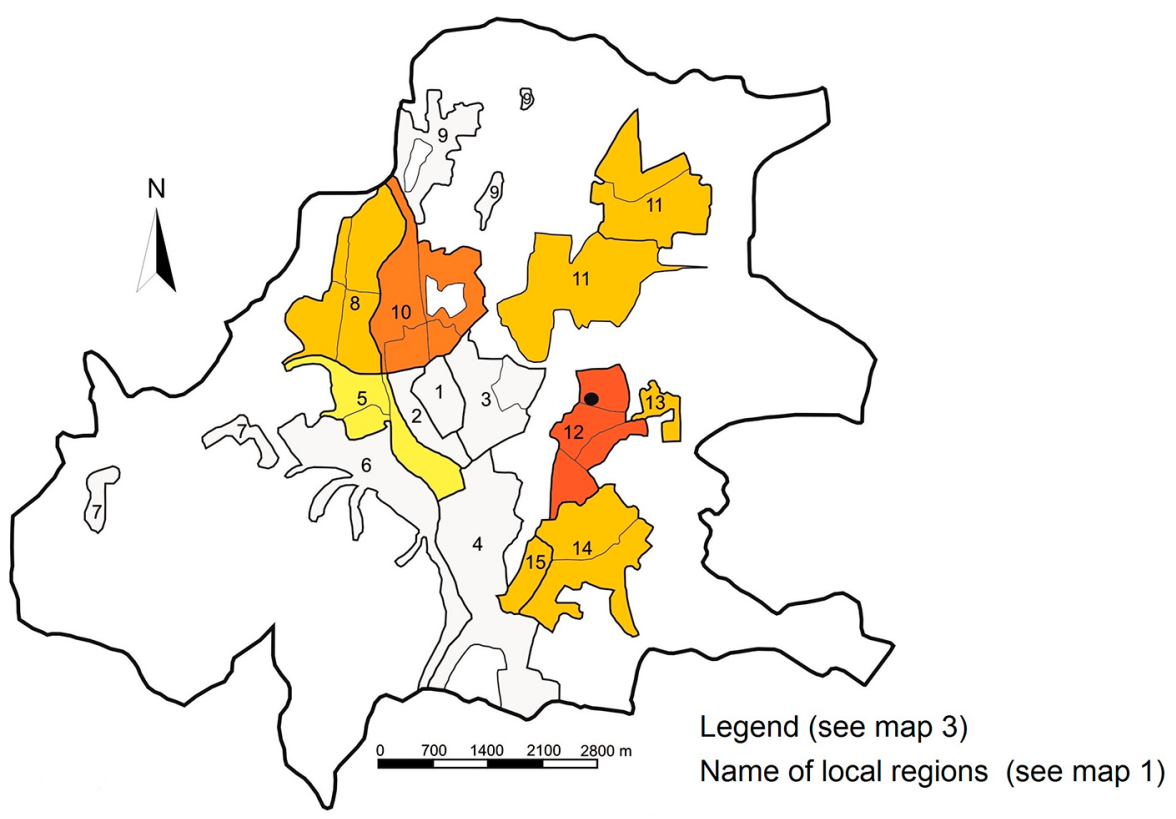

Figure 5. Frequency of visits of the retail store Billa (Čergovská street) in Prešov by the customers with the residence in Prešov Source: Authors questionnaire research

\section{Department store Tesco Stores}

Department store Tesco Stores (with the area of 4,000 $\mathrm{m}^{2}$ ) is located on the outskirts of the historical centre of Prešov (Figure 1). Its location already tells us that it will be one of the key factors of customer preferences, as there are many potential customers in the city centre (working or studying in Prešov, even from surrounding areas) and not only the residents of neighboring local regions.
However, according to the Huff Model, the Tesco department store is most likely to be chosen as a target for the purchase due to its position and due to the neighboring local region Mlynský náhon. Both local regions reach the probability of selection 0.314 and 0.318 (which is for both local regions more than a third). The interval $25.1 \%-30 \%$ got another neighboring local region Táborisko and Nemocnica. Their lower values, however, are caused by the large-scale store 


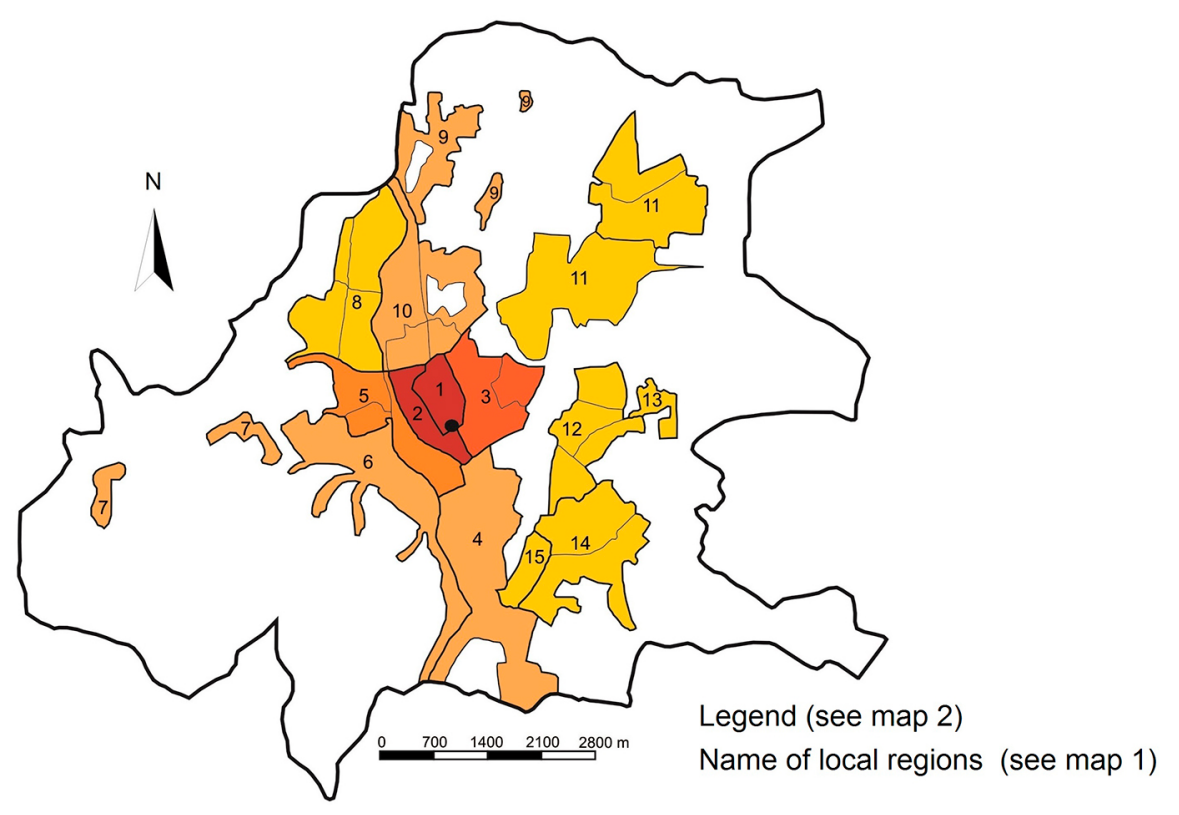

Figure 6. Selection probability of the retail store Tesco (Námestie legionárov) in Prešov by motorized customers Source: Authors research

(ZOC MAX) which is only $1 \mathrm{~km}$ away. The least shopping probability at Tesco was achieved in the local regions that are furthest from the store (including Sídlisko III, Rúrky, Družba, Pod Bikošom, and Mladost'), Nižná Šebastová and L'ubotice, Sekčov, Šalgovík, Solivar and Solná Baňa, partly Šváby (Table 2 and Figure 6). The survey revealed the most important factor of shopping choice in relation to Tesco stores which is based on its downtown location. The highest values were found in the local regions Táborisko and Nemoc- nica $(33.3 \%$ of the total number of residents in the local region chose the Tesco department store) and Calvary (30.8\%), but many respondents (not included in the results presented) living in the whole district Prešov, commuting daily to work or studies in Prešov. Since Tesco provides only paid parking place, this store is preferred by the customers who use public transport or a suburban bus, while motorized customers prefer the hypermarket Tesco on the Košická street with a free parking place.

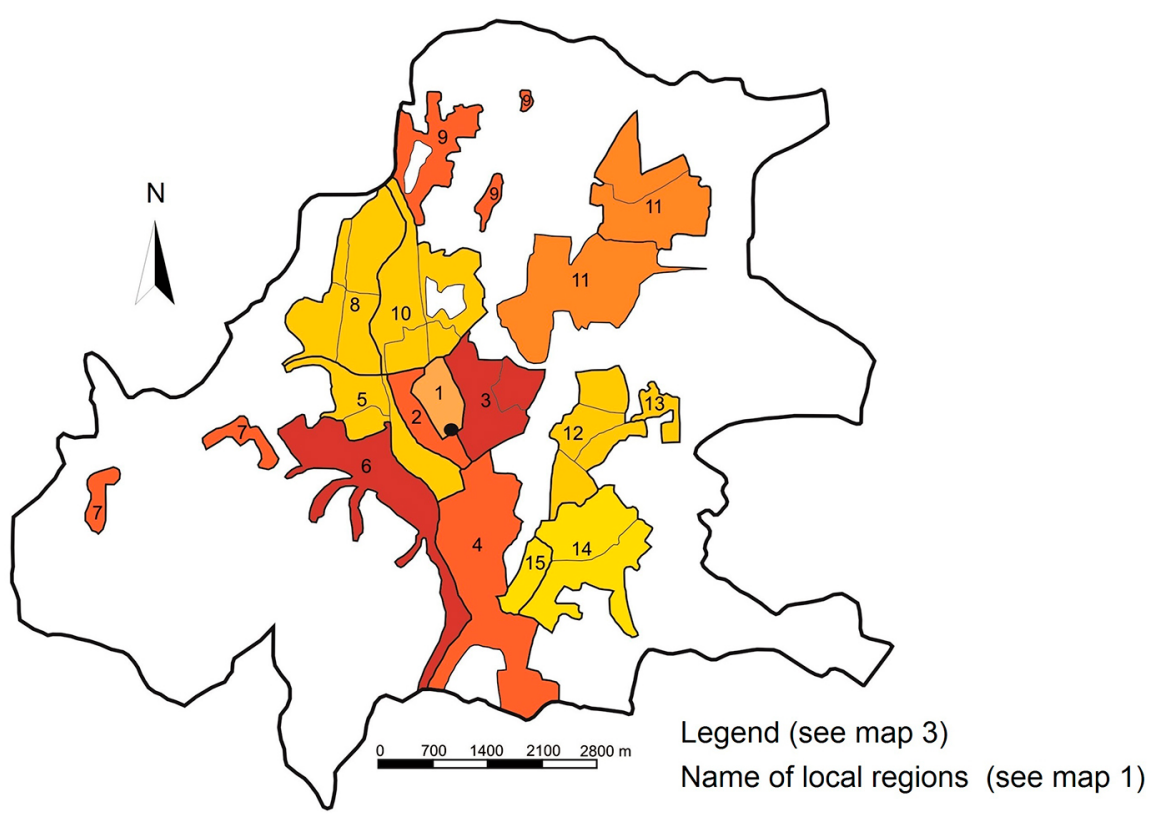

Figure 7. Selection probability of the retail store Tesco (Košická street) in Prešov by motorized customers

Source: Authors questionnaire research 


\section{Other large-scale retail stores}

At last, when calculating the Huff Model for other stores, these reach neither the minimum nor the maximum value compared to other shops. An exception might be five local regions when it comes to calculations for the Lidl store - Levočská street, in local regions (marked in gray in the Table 2), which are spatially farthest from it. These reach minimum values compared to all shops (these results confirm the results of the questionnaire survey). The calculations of the Tesco Vukov has the highest probability value calculated for the local region Sídlisko III (43\%), due to its location, as confirmed by the questionnaire survey (34\% of the total number of inhabitants in the local region chose the Tesco store Vukov for their regular purchases). The theoretical model (with a value of $33.6 \%$ ) and the results of the questionnaire survey $(75 \%)$ in connection with the Tesco store on the Košická street confirmed that the local region Prešov south, on the edge of which the hypermarket is located, reached maximum values.

\section{Conclusion}

Shopping behavior and its associated spatial mobility result from the interaction of personality characteristics of buyers as well as environmental conditions in which they live. People living in one place may under same conditions behave differently from various reasons. These may include, individual needs and motivational factors, different levels of information regarding the environmental conditions (quantity and quality of the offer), but also factors in the form of barriers which include mainly financial capabilities, spatial ability and others.

To sum it up, the Huff model, based on the comparison of calculations for nine large-scale stores in the city of Prešov, in fifteen local regions with the results of the questionnaire research. It cannot be regarded as the model which provides objective results in identifying the preferences of large stores within an urbanized area. The Huff Model presents a general theoretical picture of the purchase probability in the store. However, when it is applied in practice, factors that affect this theoretical concept have to be taken into consideration as well. This may include social, cultural, demographic aspects (age structure of the population of cities), economic aspects (e.g. income differentiation of consumers), the quality and quantity of goods, quality of services, pleasant atmosphere in shops, cleanliness and many other factors affecting the preference for a particular retail store. However, these factors cannot be incorporated into any models, because each store is specific, and general assumptions and findings do not apply here accurate- ly. Therefore, the results of this questionnaire survey of consumer shopping behavior in selected stores in Prešov are not identical with the results obtained by the theoretical calculation model. Research has also shown the existence of transitional areas, where residents commute due to shopping to two or more centres (an important role plays daily commuting to another local region, or even to another town or district, etc.). Therefore, the results of our research correspond with authors Walmsley and Lewis (1984), claiming that if there was a large modern shopping centre built in the city, offering high quality services, a wide range of goods, good prices, etc., it can be said that not all the people from the area would do their shopping in this place. On the contrary, people from distant locations might be observed doing their shopping in this shopping centre. This shows that shopping is affected by various spatial and time variables as well as by complex social phenomena.

In conclusion, that there are restrictions on the use of the Huff theoretical model, as if watching the relationship between shopping and the place of purchase, finding that the rational consumer behavior does not always take place. This refuses the previously held view that a man prefers minimal mobility for buying, and behaves only economically. However, it turns out that a part of consumers choose the shopping place based on other factors, such as a wide variety of goods, good services, diversity of services provided, size, atmosphere and other aspects as well. To conclude, this research shows that people often ignore the logic of economical thinking and are not governed only by good access and economic factors.

\section{Acknowledgment}

The article is a part of the grant research project VEGA No. 1/0857/15. It is the research of economically significant factors of reputation perception and its dominant contexts in relation to the success in the processes of e-commerce and e-marketing on the Slovak Virtual Market.

\section{References}

Civáň, M., Svorad, A., Krogmann, A. 2014. Outlet centre as a potentional development impulse: a case study of the minucipality of Voderady. http:// mnet.mendelu.cz/mendelnet2014/mnet_2014_full. pdf (accessed 13.01.2015.).

eGovernment, 2015. Portál informačného systému samosprávy mesta Prešov (Demografia). http://egov. presov.sk/default.aspx (accessed 07.01.2015.).

Gautschi, D. 1981. Specification of Patronage Models for Retail Center Choice. Journal of Marketing Research 18, 162-174. 
Hochmuth, Z., Madziková, A., Matlovič, R. 1994. Vlastiveda Prešova. Prešov: UPJŠ, 83 pp. (in Slovak with English summary)

Huff, D. 1962. A note on the limitation of interurban gravity models. Land Economics 38, 64-66.

Huff, D. 1963. A probabilistic analysis of shopping center trade areas. Land Economics 39, 81-90.

Huff, D. 1964. Defining and Estinating a Trading Area. Journal of Marketing 28, 34-38.

Križan, F. 2009. Globalization of Retailing: the Definition of Fundamental Processes and their Analysis in the Slovak Retail Geography. Geografický časopis/Geographical Journal 61, 49-68. (in Slovak with English summary)

Križan, F., Tolmáči, L. 2012. Geographic Information Systems as Visualization Tools in the Retail Field: Introduction. Možnosti využitia geografickoinformačného systému ako zdroja strategickej inovácie podniku $\mathrm{z}$ hladiska posilnenia jeho konkurencieschopnosti podnikov. Bratislava: Vydavatel'stvo Ekonóm, 57-65. (in Slovak)

Križan, F., Lauko, V. 2014. Retail Geography. Introduction. Bratislava: Univerzita Komenského, 196 pp. (in Slovak)

Kunc, J., Tonev, P., Frantál, B., Szczyrba, Z. 2012a. Retail Gravity Models, Shopping Habits a Shopping Centres: The Caseof the Brno Agglomeration (a Contribution to the Study of Daily Urban Systems). Sociologický časopis/Czech Sociological Review 48, 879-910.

Kunc, J., Tonev, P., Szczyrba, Z., Frantál, B. 2012b. Commuting for Retail Shopping as a Part of the Daily Urban System (Brno, the Czech Republic). Geographica Technica 13, 36-45.

Kunc, J., Maryáš, J., Tonev, P., Frantál, B., Siwek, T., Halás, M., Klapka, P., Szczyrba, Z., Zuskáčová, V. 2013. Spatiotemporal Patterns of Purchasing Behavior of the Czech Population. Brno: Masarykova univerzita, 194 pp. (in Czech with English summary)

Maryáš, J. 1983. The Methods of the Retail Store and Sphere Selection. Zprávy GgÚ ČSAV 20, 61-81. (in Czech)

Maryáš, J., Kunc, J., Tonev, P., Szczyrba, Z. 2014. Shopping and services related travel in the hinterland of Brno: changes from the socialist period to present. Moravian Geographical Reports 22, 18-28.

Matlovič, R. 1998. Spatial Structure Geography of the City Prešov. Prešovská univerzita, Fakulta humanitných a prírodných vied, Katedra geografie, Prešov, 260 pp. (in Slovak with English summary)

Matlovič, R., Ira, V., Szczyrba, Z., Sýkora, L. 20o1. Procesy transformacyjne struktury przestrzennej miast postkomunistycznych (na przykładzie Pragi, Bratysławy, Ołomuńca oraz Preszowa). Miasto postsocjalistytczne - organizacja przestrzeni miejskiej i jej przemiany (II), XIV Konwersatorium
Wiedzy o Mieście. Łodź: Uniwersitet Łódzki. 9-21. (in Polish with English summary)

Mitríková, J. 2005. Regional-geographical Aspects of the Retail Development Assessment in Slovakia after 1989. Acta Facultatis Studiorum Humanitatis et Naturae Universitatis Prešoviensis, Prírodné vedy, Folia Geographica 8, 5-12. (in Slovak with English summary)

Mitríková (born. Fertalová), J., Varga, P. 2007. Application of the Huff's probability model on selected large-area retail units in Košice in the context of transformational changes in retail after 1989 in Slovakia. Revija za geografijo: journal for geography 2, 63-72.

Mitríková, J. 2008. Geographical Aspects of the Retail and Shopping Behavior Transformation in Slovakia (Case Studies of cities Prešov and Košice). Geografické práce 14, Fakulta humanitných a prírodných vied, Prešov, 213 pp. (in Slovak with English summary)

Mitríková, J., Menyhértová, I. 2008. Wochenenfremdenverkehr der Einwohner der Stadt Košice in Betracht der neuen Art der Freizeitverbringung in den Vergnügungseinkaufszentren. Revija za geografijo: journal for geography 3, 75-86.

Mitríková, J., Varga, P. 2008. The Huff'sprobability model and its application on selected large-area retail units in Košice. Acta Facultatis Studiorum Humanitatis et Naturae Universitatis Prešoviensis, Prírodné vedy, Folia Geographica 12, 77-82.

Mitríková, J. 2010a. Retail Transformation in Slovakia. Geografické poznatky bez hraníc: výber z mad’arských a slovenských príspevkov z fyzickej a humánnej geografie. Univerzita Pavla Jozefa Šafárika v Košiciach, Prírodovedecká fakulta, Inštitút geografie, Košice, 244-249. (in Slovak)

Mitríková, J. 2010b. A kiskereskedelem átalakulása Szlovákiában. Földrajzi szemel vények határok nélkül: napjaink magyar és szlovák természet-, társadalom- és gazdaságföldrajzi írásaiból. Regionális Kutatások Központja, Pécs 245-250. (in Hungarian)

Mitríková, J., Tomčíková, I., Lukáčová, A. 2012. Košice Inhabitants Spending their Leisure Time in Shopping Centers as a New Kind of Weekend Tourism. In: Význam ludského potenciálu $\mathrm{v}$ regionálnom rozvoji. Zborník vedeckých prác z medzinárodnej vedeckej konferencie. Východoslovenská agentúra pre rozvoj, Podhájska, 69-9o. (in Slovak with English summary)

Pražská, L., Jindra, J. a kol. 1998. Obchodní podnikání. Retail management, management Press, Praha, 874 pp. (in Czech)

Reilly, W. 1929. Methods for the Study of Retail Relationships. University of Texas Bulletin no. 2944, University of Texas, Austin. 
Reilly, W. 1931. The Law of Retail Gravitation. GP Putnam \& Sons, New York.

Schiffman, L. G., Kanuk, L.L 2004. Nákupní chování. Velká kniha k tématu Consumer Behaviour., Computer Press, Brno, 633 pp. (in Czech)

Spilková, J., Radová L. 2011. The Formation of Identity in Teenage Mall Microculture: A Case Study of Teenagers in Czech Malls. Sociologický časopis/ Czech Sociological Review 47, 565-586.

Spilková, J. 2012. Geografie maloobchodu a spotřeby: věda o nakupování. Praha: Karolinum. (in Czech)

Szczyrba, Z. 2005a. Maloobchod v ČR po roce 1989. Vývoj a trendy se zaměřením na geografickou organizaci, Univerzita Palackého v Olomouci, Olomouc, 126 pp. (in Czech)

Szczyrba, Z. 2005b. Nákupní centra v České republice - nová forma zábavy a nákupní turistiky. Politechnika Opolska, Opole, 116 pp. (in Czech)
Szczyrba, Z. 2006. Geografie obchodu - se zaměřením na současné trendy $\mathrm{v}$ maloobchodě. Univerzita Palackého v Olomouci, Olomouc, 9o pp. (in Czech) Trembošová, M. 2008. Huff Selection Probability Model Applied in the Shopping Centers of Nitra. Geografická revue 4, 448- 459. (in Slovak)

Trembošová, M. 2010. Selected Aspects of the Retail Transformation in Nitra in the Years 1992-2008. Geografický časopis 62, 49-73. (in Slovak with English summary)

Trembošová, M. 2012. Geografické aspekty maloobchodnej siete mesta Nitra (Geographical Aspects of the Retail Network in Nitra). Univerzita Konštantína Filozofa, Nitra, 157 pp.

Trembošová, M., Dubcová, A. 2013. Retail Development in Nitra under the New Market Conditions after 1989. Acta Geographica Universitatis Comenianae 57, 213-230. (in Slovak with English summary)

Walmsley, D.J., Lewis, G.J. 1984. Human Geography: Behavioural Approaches. Longman, London. 